DOI: https://doi.org/10.47405/mjssh.v5i12.599

\begin{tabular}{|c|c|}
\hline (8) & Malaysian Journal of Social Sciences and Humanities (MJSSH) \\
\hline Malaysian Journal of & Volume 5, Issue 12, December 2020 \\
\hline 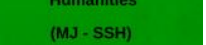 & e-ISSN : 2504-8562 \\
\hline & $\begin{array}{l}\text { Journal home page: } \\
\text { www.msocialsciences.com }\end{array}$ \\
\hline
\end{tabular}

\title{
Pengaruh Motivasi Kerja Intrinsik dan Ekstrinsik Terhadap Keefisienan Kerja Guru Sekolah Menengah di Negeri Sabah
}

\author{
Arzizul Bin Antin¹, Dg Norizah AgKiflee @ Dzulkifli1, Muhammad Suhaimi Taat', Roslee Talip ${ }^{1}$ \\ ${ }^{1}$ Fakulti Psikologi dan Pendidikan, Universiti Malaysia Sabah (UMS)
}

Correspondence: Arzizul bin Antin (zzul1446@gmail.com)

\begin{abstract}
Abstrak
Kajian ini bertujuan untuk mengenal pasti sama ada terdapat pengaruh antara motivasi kerja intrinsik dan motivasi kerja ekstrinsik terhadap tahap keefisienan kerja guru sekolah menengah di negeri Sabah. Kajian ini menggunakan pendekatan kuantitatif dan reka bentuk bukan eksperimen. Kaedah kajian yang digunakan merupakan kaedah tinjauan yang melibatkan seramai 375 orang guru sekolah menengah yang dijadikan sampel kajian. Sampel kajian ini dipilih menggunakan teknik pensampelan rawak mudah. Instrumen soal selidik digunakan untuk mengukur variabel kajian. Ujian Regresi Pelbagai menerusi Perisian Statistical Package for Social Sciences (SPSS) pula digunakan untuk menganalisis data mentah daripada responden. Dapatan kajian menunjukkan motivasi kerja intrinsik guru (Beta $=0.31),(\mathrm{t}=6.76, \mathrm{P}<0.05)$ merupakan peramal yang lebih signifikan berbanding motivasi kerja ekstrinsik guru $($ Beta $=0.29),(\mathrm{t}=8.41, \mathrm{P}<0.05)$ terhadap keefisienan kerja guru sekolah menengah di negeri Sabah. Pengaruh keseluruhan pula menunjukkan motivasi kerja boleh menerangkan secara signifikan sebanyak 60 peratus daripada varians dalam variabel bersandar iaitu keefisienan kerja guru $[\mathrm{F}(2,372)=104.25, \mathrm{P}<0.05)]$. Kesemua variabel berhubung secara positif. Kajian ini diharap dapat memberikan input baharu berkaitan dengan aspek-aspek kajian yang seterusnya bermanfaat untuk memperkasa profesion keguruan dan sistem pendidikan negara secara holistik.
\end{abstract}

Kata kunci: motivasi kerja intrinsik, motivasi kerja ekstrinsik, keefisienan kerja guru

\section{Influence of Intrinsic and Extrinsic Work Motivation on the Efficiency of Secondary School Teachers in Sabah State}

\begin{abstract}
This study aims to identify whether there is an influence between intrinsic work motivation and extrinsic work motivation on the level of work efficiency of secondary school teachers in Sabah state. This study uses a quantitative approach, a non-experimental research design and survey method involving a total of 375 high school teachers who were used as a research sample. This sample was determined using a simple random sampling technique. Questionnaire instruments were used to obtain information from the respondents. Multiple Regression Analysis using Statistical Package for Social Sciences (SPSS) Software were used to analyze the primary data from the respondents. Finding of this study show that teacher's intrinsic work motivation (Beta $=0.31),(\mathrm{t}=6.76, \mathrm{P}<0.05)$ is a more significant predictor compare to teacher's extrinsic work motivation (Beta $=0.29),(\mathrm{t}=8.41, \mathrm{P}<0.05)$ on the work efficiency of secondary school teachers in Sabah state. Overall result shows that work motivation can significantly explained 60 percent of the variance in the teacher's work efficiency [F (2,
\end{abstract}


$372)=104.25, \mathrm{P}<0.05)$ ]. All variables are positively related. Results of this study will provide new input related to the aspects of the study which is beneficial to strengthen the teaching profession and enhance our national education system holistically.

Keywords: intrinsic work motivation, extrinsic work motivation, teacher's work efficiency

\section{Pengenalan}

Keefisienan kerja guru sememangnya menjadi salah satu aspek yang dipandang penting oleh Kementerian Pendidikan. Di samping menunjukkan tahap keefisienan kerja yang tinggi, kementerian mengharapkan guru dapat memberikan sepenuh taat setia, menunjukkan semangat berdedikasi, berkerja keras, dan menunjukkan komitmen yang tinggi sebagai seorang guru (Tajulashikin, Fazura, \& Mohd Burhan, 2013; Ubom \& Joshua, 2004). Keefisienan kerja guru akan mempengaruhi sistem pendidikan secara terus kerana guru yang efisien akan melaksanakan tugas dengan berkualiti yang seterusnya menyumbang kepada kecemerlangan sistem pendidikan negara seperti yang dijelaskan oleh Sipon (2007) guru merupakan peranan utama dalam memastikan kegemilangan mutu pendidikan negara. Oleh itu, bagi Memastikan guru boleh menjalankan tugas dengan efisien maka aspek motivasi guru perlu diberikan perhatian utama kerana motivasi guru memberikan kesan signifikan dalam mempengaruhi hasil kerja guru (Subasi, 2009) yang seterusnya akan meningkatkan mutu pendidikan negara kerana guru merupakan barisan hadapan yang menyumbang kepada keberhasilan sistem pendidikan negara (Fatmasari, 2014).

\section{Pernyataan Masalah}

Keefisienan kerja guru merujuk kepada cara bagaimana guru melaksanakan tugas dan tanggungjawab yang diberi menggunakan pelbagai kaedah bertepatan dengan pendapat Syed Ismail dan Ahmad Subki (2010), guru yang efisien seharusnya memiliki, kemahiran yang pelbagai, komitmen dan dedikasi yang tinggi terhadap pekerjaannya.

Kamaruzaman (2007) dan Syed Kamaruzaman et al. (2017) menyatakan keefisienan kerja guru menurun apabila guru banyak diberikan tugas selain daripada mengajar. Hal ini menjadi semakin mencabar apabila para guru terkejar-kejar untuk menyempurnakan tugasan tersebut mengikut masa yang telah ditetapkan. Hal ini seterusnya menyebabkan guru kehilangan fokus dan kurang bersungguhsungguh dalam menjalankan tugas tersebut. Tugas guru yang semakin rumit dan mencabar menyebabkan guru merasa tugas yang asalnya merupakan satu bentuk tanggungjawab berubah menjadi satu bentuk beban. Pernyataan ini disokong oleh Hong dan Aziah Ismail (2015) yang menjelaskan keefisienan kerja guru terjejas apabila timbulnya perasaan gelisah, marah, kekecewaan dan tidak puas hati dalam kalangan guru terhadap tugas yang dilakabkannya.

Hal ini disokong oleh Raja Maria (2011) yang menjelaskan bahawa tugas yang terlalu banyak akan menyebabkan seseorang guru itu berasa kecewa dan bertindak diluar kawalan secara spontan. Azizi Yahaya, Kim dan Sharifudin (2010) memperkukuh lagi pendapat ini dengan menyatakan bahawa tugas yang banyak melahirkan perasaan tidak selesa yang menyebabkan adanya emosi negatif seperti marah, kecewa, dan keletihan. Perasaan-perasaan negatif ini akan menyebabkan turunnya tahap motivasi dan keefisienan kerja guru kerana guru tidak mungkin dapat berfungsi dengan efisien sekiranya minda mereka dikuasai oleh perasaan-perasaan negatif.

Dalam memastikan tahap keefisienan kerja guru berada pada tahap yang maksimum maka motivasi guru juga perlu berada pada tahap yang terbaik. Norashid dan Hamzah (2014) merumuskan bahawa motivasi guru mempunyai hubungan dengan tugas yang dilaksanakan oleh guru. Penney dan Spector (2005) dan Fox, Spector dan Miles (2001) pula menyatakan pendapat bahawa pertambahan tugas sama ada tugas akademik mahupun tugas bukan akademik akan menyebabkan penurunan tahap motivasi guru sehingga akhirnya menyebabkan guru tidak melaksanakan tugas dengan efisien. 


\section{Objektif Kajian}

Berikut merupakan objektif kajian yang ingin dikaji:

i. Mengkaji pengaruh motivasi kerja intrinsik dan motivasi kerja ekstrinsik terhadap keefisienan kerja guru sekolah menengah di negeri Sabah.

\section{Hipotesis Kajian}

Berikut merupakan hipotesis alternatif dalam kajian ini.

$\mathrm{Ha}^{1}$ : Terdapat pengaruh yang signifikan motivasi kerja intrinsik dan motivasi kerja ekstrinsik terhadap keefisienan kerja guru sekolah menengah di negeri Sabah.

\section{Sorotan Literatur}

\section{Teori Pengurusan Saintifik Frederick Winslow Taylor}

Teori pengurusan saintifik diperkenalkan oleh Frederick Winslow Taylor. Beliau telah membuat pemerhatian terhadap fungsi dan pergerakan setiap pekerja dalam menjalankan tugas. Beliau kemudiannya membuat analisis berdasarkan pemerhatian beliau untuk menjadikan pergerakan setiap pekerja dalam menjalankan tugas lebih efisien. Pandangan Taylor dalam teori ini telah memberikan pengaruh yang besar sehingga ke hari ini (Ada \& Ada, 2013). Taylor menggariskan empat prinsip pengurusan saintifik iaitu pemilihan kaedah terbaik, kerjasama, pembahagian tugas yang adil, dan insentif (Turan, 2015).

\section{Teori Motivasi Dua Faktor Herzberg}

Teori Motivasi Manusia yang diasaskan oleh Frederick Irving Herzberg pada tahun 1966 yang menghuraikan motivasi manusia dalam dunia pekerjaan mereka. Herzberg telah membentuk teori motivasi dua faktor ( $t$ wo-factor theory of motivation). Dua faktor dalam motivasi ini dikenali sebagai 'dissatisfier-satisfier', 'motivator-hygience', dan ekstrinsik-intrinsik (Herzerbg, 1966). Motivasi intrinsik merupakan faktor yang melahirkan perasaan puas dalam melaksanakan sesuatu pekerjaan. Faktor ini memotivasikan dengan perubahan dalam budaya kerja. Budaya kerja ini mencabar dan mengembangkan potensi dalam diri pekerja. Selain daripada peluang mengembangkan potensi diri, faktor penghargaan, pencapaian, kepuasan diri menjadi faktor yang mendorong lahirnya motivasi ini.

Motivasi ekstrinsik pula merupakan faktor yang mempengaruhi lahirnya perasaan tidak puas hati dalam melaksanakan sesuatu pekerjaan. Faktor ini menekankan bahawa gaji haruslah bertepatan ataupun berkesesuaian dengan tahap kerja. Selain itu, faktor tempat kerja yang selesa, polisi tempat kerja, Tawaran skim bersara, ganjaran, insentif, waktu kerja, kod pakaian, penghargaan, dan kenaikan pangkat merupakan faktor yang penting mempengaruhi motivasi ekstrinsik (Salanova \& Kirmanen, 2010).

\section{Pengaruh Motivasi Kerja terhadap Keefisienan Kerja Guru}

Motivasi merupakan faktor penting yang mempengaruhi keefisienan kerja yang seterusnya akan mempengaruhi kejayaan dan keberhasilan organisasi dalam mencapai visi dan misi. Pekerja yang memiliki tahap motivasi yang rendah akan mengakibatkan kelemahan dalam sistem pengurusan dan pentadbiran sesebuah organisasi akibat kurangnya komitmen semasa menjalankan tugas yang diberikan (Azlinda, 2013). Oleh itu, dalam konteks sekolah, matlamat utama sekolah adalah untuk mewujudkan iklim sekolah positif agar dapat mendorong dan menggalakkan lahirnya motivasi guru yang seterusnya akan meningkatkan keefisienan kerja mereka (Eh Tem, 2013). 
Nurul Jalilah (2013) yang menjalankan kajian berkaitan pengaruh kepimpinan instruksional pengetua terhadap motivasi guru menegaskan motivasi merupakan salah satu faktor yang mendorong guru untuk mencapai matlamatnya. Motivasi sering dikaitkan dengan kecemerlangan kerja dan prestasi kerja sama ada guru secara individu atau sekolah secara keseluruhannya. Guru yang bermotivasi tinggi sangat mementingkan keefisienan kerja. Sebaliknya, guru yang bermotivasi rendah kurang mementingkan keefisienan kerjanya. Tambahan lagi, guru yang bermotivasi tinggi akan menunjukkan tahap keefisienan kerja tinggi yang seterusnya membolehkan dan membantu sekolah mencapai apa sahaja matlamat yang telah disasarkan. Zainab dan Khairunnisa (2015) juga menyokong pernyataan ini dengan menegaskan aspek motivasi penting dalam mempengaruhi keefisienan kerja guru.

Pengkaji luar negara seperti Onjoro, Arogo, dan Embeywa (2015) menjalankan kajian berkaitan motivasi kepimpinan dan penyeliaan terhadap peningkatan tahap keefisienan kerja guru dan pekerja institusi. Dapatan kajian ini menunjukkan adanya pengaruh yang signifikan antara faktor motivasi dan keefisienan kerja guru. Menurut para pengkaji, motivasi guru penting bagi menjamin kualiti dalam sistem pendidikan. Strategi peningkatan motivasi guru seperti program latihan dan pengembangan guru, kenaikan pangkat, gaji yang berkesesuaian, program persaraan, tempat kerja yang kondusif, dan terlibat dalam membuat keputusan dapat memperkaya motivasi guru bagi meningkatkan keefisienan kerja guru. Hal ini sangat penting kerana motivasi guru merupakan kunci kepada kualiti pendidikan. Tanpa adanya guru yang efisien, mustahil untuk melahirkan pelajar yang berkualiti dan mencapai matlamat sekolah.

Seterusnya, kajian M. Nur Mustafa dan Norasmah (2010) juga menunjukkan adanya pengaruh antara motivasi guru dan keefisienan kerja guru. Kajian ini dijalankan di Sekolah Menengah Atas Pekan Baru, Riau. Analisis regresi menunjukkan variabel motivasi guru menyumbang sebanyak 61 peratus kepada variabel keefisienan kerja guru. Analisis ini menunjukkan motivasi guru mempunyai pengaruh yang signifikan terhadap keefisienan kerja guru. Pengkaji juga menegaskan adalah perlu untuk meningkatkan motivasi guru bagi meningkatkan tahap keefisienan kerja guru

Di samping itu, kajian Brahmansari dan Prayitno (2008) ke atas 325 orang responden yang datanya dikutip menggunakan borang soal selidik dan dianalisis menggunakan ujian regresi berganda juga menunjukkan adanya pengaruh yang signifikan antara variabel motivasi terhadap keefisienan kerja. Motivasi kerja yang tinggi menunjukkan indikasi bahawa keinginan untuk melakukan sesuatu tugas adalah tinggi. Motivasi guru boleh berupa motivasi untuk keperluan diri sendiri, keperluan pekerjaan, penghargaan, dan peluang untuk meningkatkan kemahiran diri. Dapatan kajian ni selari dengan dapatan kajian $\mathrm{Hu}$ et al. (2007) yang melaporkan motivasi guru mempunyai pengaruh terhadap keefisienan kerja guru dan motivasi guru ini boleh ditingkatkan dengan pemberian pelbagai insentif.

\section{Metod Kajian}

\section{Reka Bentuk dan Kaedah Kajian}

Reka bentuk yang dipilih dalam kajian ini ialah reka bentuk bukan eksperimen. Kaedah kajian yang dipilih pula ialah kaedah kuantitatif secara tinjauan bertepatan dengan pendapat Creswell (2009) yang menjelaskan kaedah tinjauan sesuai digunakan bagi kajian yang menggunakan reka bentuk bukan eksperimen. Teknik soalan berasaskan soal selidik pula digunakan bagi mendapatkan maklumat daripada responden. Instrumen yang dibina oleh Onjoro, Arogo dan Embeywa (2015) dan Salanova dan Kirmanen (2010) telah digunakan untuk mengukur variabel-variabel kajian. Instrumen ini telah diubah suai mengikut kesesuaian kajian ini. Data mentah dianalisis menggunakan perisian Statistical Package for Social Sciences (SPSS) dengan menjalankan ujian Regresi Pelbagai. 


\section{Lokasi Kajian}

Kajian ini dijalankan di seluruh negeri Sabah. Terdapat 24 Pejabat Pelajaran Daerah (PPD) dan sebanyak 219 buah sekolah menengah di negeri Sabah. Namun begitu, dalam kajian ini pengkaji hanya akan memilih dua buah sekolah menengah dari setiap PPD bagi memenuhi saiz responden yang diperlukan iaitu sebanyak 375 orang guru sekolah menengah.

\section{Populasi dan Sampel Kajian}

Populasi kajian adalah seramai 16084 orang guru sekolah menengah di seluruh Sabah. Namun begitu, daripada jumlah ini, hanya 375 orang guru sahaja yang dipilih untuk menjadi sampel kajian. Kaedah pensampelan yang digunakan dalam kajian ini adalah kaedah pensampelan rawak mudah. Hal ini bermaksud setiap guru daripada populasi mempunyai peluang yang sama rata untuk dipilih sebagai sampel kajian bertepatan dengan pendapat Merican (2009), menerusi pensampelan rawak mudah, setiap elemen dalam populasi mempunyai peluang yang sama untuk dipilih sebagai sampel kajian. Jadual penentuan saiz sampel mengikut Krejcie dan Morgan (1970) telah dirujuk bagi menentukan jumlah sampel kajian. Berdasarkan jadual penentuan saiz sampel Krejcie dan Morgan (1970), telah ditetapkan berapakah jumlah sampel yang diperlukan daripada jumlah populasi yang ada. Selain itu, bagi memperkukuh kebolehpercayaan bilangan sampel yang dipilih adalah mencukupi maka pengiraan jumlah bilangan sampel mengikut formula pengiraan saiz sampel Cochran (1977) telah dilaksanakan (Bartlett, Kotrlik \& Higgins, 2001).

\section{Kesahan dan Kebolehpercayaan Instrumen Kajian}

Analisis kesahan dan kebolehpercayaan item telah dilaksanakan semasa fasa kajian rintis yang melibatkan seramai 100 orang guru Sekolah Menengah yang terpilih. Jumlah sampel kajian rintis ini bertepatan dengan pendapat Connely (2008) yang menyarankan jumlah sampel bagi kajian rintis adalah sebanyak 10 peratus daripada jumlah sampel sebenar. Oleh itu, sampel kajian rintis dalam kajian ini melebihi jumlah yang diperuntukkan. Bagi menguji Kesahan instrumen soal selidik, ujian EFA menggunakan perisian SPSS telah dijalankan. Manakala, ujian kebolehpercayaan dengan merujuk kepada nilai Alpha Cronbach telah digunakan bagi menganalisis kebolehpercyaan item. Jadual 1 menunjukkan hasil analisis terhadap Indeks Kaiser-Meyer-Oklin (KMO) dan ujian Bartlett's bagi ujian kecukupan sampel dan item soal selidik serta ujian kebolehpercayaan dengan melihat nilai Alpha Cronbach.

Jadual 1: Analisis Kesahan dan Kebolehpercayaan Instrumen

\begin{tabular}{ccccc}
\hline Bil. & Konstruk yang Diuji & KMO & Bartlett's (Sig) Alpha Cronbach \\
\hline Motivasi Guru & 0.61 & 0.00 & 0.85 \\
& Keefisienan Kerja Gurı & 0.61 & 0.00 & 0.86 \\
\hline
\end{tabular}

Berdasarkan jadual 1, nilai KMO bagi konstruk motivasi guru ialah 0.61 dan nilai KMO bagi keefisienan kerja guru juga 0.61. Nilai kedua-dua konstruk yang diuji melebihi nilai minimum bagi ujian KMO iaitu 0.50. Bagi ujian Bartlett's pula, kesemua konstruk yang diuji berada pada aras signifikan 0.00. Hair et al. (2010) menjelaskan item layak untuk dianalisis faktor dan diterima sekiranya nilai KMO melebihi 0.50 dan mempunyai nilai yang signifikan. Oleh itu, kedua-dua konstruk yang diuji dalam kajian ini sesuai untuk dianalisis faktor.

Selain melihat pada nilai KMO dan Bartlett's, kesahan item diperincikan dengan membuat ujian kesahan konstruk dengan melihat kepada nilai faktor muatan (factor loading). Nilai faktor muatan bagi item insrumen soal selididk adalah melebihi nilai minimum faktor muatan yang boleh dianalisis faktor iaitu 0.40 (Hair, Black, \& Anderson, 2010). Nilai Alpha Cronbach juga menunjukkan kedua-dua instrumen mempunyai tahap kebolehpercayaan yang tinggi iaitu motivasi guru (0.85) dan keefisienan kerja guru (0.86). 


\section{Hasil Kajian}

\section{Ha $^{1}$ : Terdapatpengaruh yang signifikan motivasi kerja intrinsik dan motivasi kerja ekstrinsik terhadap keefisienan kerja guru sekolah menengah di negeri Sabah.}

Jadual 2 menunjukkan ringkasan ujian Regresi Pelbagai. Manakala, jadual 3 pula menunjukkan hasil ujian Anova. Hasil ujian regresi yang dijalankan menunjukkan adanya regresi yang sederhana model regresi yang mengandungi variabel tetap iaitu motivasi kerja intrinsik dan motivasi kerja ekstrinsik yang boleh menerangkan secara signifikan sebanyak 60 peratus daripada varians dalam variabel bersandar iaitu keefisienan kerja guru $[\mathrm{F}(2,372)=104.25, \mathrm{P}<0.05)]$.

Jadual 2: Ringkasan Model

\begin{tabular}{|c|c|c|c|}
\hline Model & $\mathbf{R}$ & R Square & $\begin{array}{r}\text { Adjusted R Square Std. Error of the } \\
\text { Estimate }\end{array}$ \\
\hline 1 & $.60^{\mathrm{a}}$ & .36 & $.37 \quad .30$ \\
\hline
\end{tabular}

Jadual 3: Analisis ANOVA

\begin{tabular}{ccccccc}
\hline & Model & Sum of Squares & $\boldsymbol{d f}$ & Mean Square & F & Sig. \\
\hline 1 & Regression & 18.56 & 2 & 9.28 & 104.25 & $.00^{\mathrm{b}}$ \\
& Residual & 33.12 & 372 & 0.09 & & \\
\hline Jumlah & 51.66 & 374 & & & \\
\hline
\end{tabular}

Jadual 4 pula menunjukkan hasil analisis koefisien yang menunjukkan pekali regresi kedua-dua motivasi kerja. Daripada jadual ini, motivasi kerja intrinsik guru (Beta=0.31), $(\mathrm{t}=6.76, \mathrm{P}<0.05)$ merupakan peramal yang lebih signifikan berbanding motivasi kerja ekstrinsik guru $(B e t a=0.29)$, $(\mathrm{t}=8.41, \mathrm{P}<0.05)$ terhadap keefisienan kerja guru sekolah menengah di negeri Sabah. Kedua-dua variabel ini menunjukkan pengaruh yang lemah tetapi positif.

Jadual 4: Analisis Koefisien

\begin{tabular}{|c|c|c|c|c|c|}
\hline \multirow[t]{2}{*}{ Model } & \multicolumn{2}{|c|}{$\begin{array}{c}\text { Unstandardized } \\
\text { Coefficients }\end{array}$} & \multirow{2}{*}{$\begin{array}{c}\begin{array}{c}\text { Standardized } \\
\text { Coeffiients }\end{array} \\
\text { Beta }\end{array}$} & \multirow[t]{2}{*}{$\mathbf{t}$} & \multirow[t]{2}{*}{ Sig. } \\
\hline & B & Std Error & & & \\
\hline (Tetap) & 1.74 & 0.18 & & 9.78 & 0.00 \\
\hline Motivasi kerja Intrinsik & 0.30 & 0.04 & 0.31 & 6.76 & 0.00 \\
\hline Motivasi kerja ekstrinsik & 0.25 & 0.30 & 0.29 & 8.41 & 0.00 \\
\hline
\end{tabular}

Oleh itu, dapat disimpulkan, motivasi kerja intrinsik dan motivasi kerja ekstrinsik mempunyai pengaruh sederhana terhadap keefisienan kerja guru sekolah menengah di negeri Sabah. Kesemua variabel berhubung secara positif. Justeru itu, hipotesis alternatif yang menyatakan terdapat pengaruh yang signifikan antara motivasi kerja intrinsik dan motivasi kerja ekstrinsik terhadap keefisienan kerja guru sekolah menengah di negeri Sabah diterima.

\section{Perbincangan Kajian}

Dapatan kajian ini selari dengan hasil kajian pengkaji-pengkaji daripada dalam dan luar negara. Motivasi kerja guru sesungguhnya merupakan faktor penting yang mempengaruhi keefisienan kerja yang seterusnya akan mempengaruhi kejayaan dan keberhasilan organisasi dalam mencapai matlamat sekolah (Azlinda Jaini, 2013). Kajian Nurul Jalilah (2013) turut menyokong dapatan kajian ini yang menjelaskan guru yang bermotivasi tinggi sangat mementingkan keefisienan kerja. Sebaliknya, guru yang bermotivasi rendah kurang mementingkan keefisienan kerjanya. Tambahan lagi, guru yang 
bermotivasi tinggi akan menunjukkan tahap keefisienan kerja tinggi yang seterusnya dan sekolah mencapai apa sahaja matlamat yang telah disasarkan.

Pengkaji luar negara seperti Onjoro, Arogo dan Embeywa (2015) juga menyokong dapatan kajian ini dengan menjelaskan motivasi guru penting bagi menjamin kualiti dalam sistem pendidikan. Strategi peningkatan motivasi guru seperti program latihan dan pengembangan profesionalisme guru, kenaikan pangkat, gaji yang bersesuaian, program persaraan, tempat kerja yang kondusif, dan terlibat dalam membuat keputusan dapat memperkaya motivasi guru bagi meningkatkan keefisienan kerja guru. Hal ini sangat penting kerana motivasi guru merupakan kunci kepada kualiti pendidikan dan tanpa adanya guru yang efisien, mustahil untuk mencapai matlamat sekolah dan membentuk pelajar yang berkualiti untuk kemajuan negara. Seterusnya, kajian M. Nur dan Norasmah (2010) juga selari dengan dapatan kajian ini yang menunjukkan motivasi guru mempunyai pengaruh positif signifikan yang sederhana terhadap keefisienan kerja guru.

Di samping itu, kajian Brahmansari dan Prayitno (2008) menyokong dapatan kajian ini yang menjelaskan motivasi kerja intrinsik lebih dominan dalam mempengaruhi keefisienan kerja guru kerana motivasi kerja yang tinggi menunjukkan indikasi bahawa keinginan untuk melakukan sesuatu tugas atas keperluan diri sendiri adalah tinggi. Selain itu, Kelvin (2016) juga menjelaskan guru melaksanakan tugas sebagai guru kerana keinginan mereka sendiri khususnya dalam proses pengajaran dan pembelajaran. Selain itu, mereka melaksanakan tugas dengan efisien kerana menjadi seorang guru sememangnya profesion pilihan mereka. Kesannya, guru melaksanakan tugas dengan rela hati dan hal ini meningkatkan tahap keefisienan kerja mereka.

Kajian Aacha (2010) juga menunjukkan adanya pengaruh yang positif antara motivasi kerja intrinsik dan motivasi kerja ekstrinsik terhadap keefisienan kerja guru. Guru yang mempunyai tahap motivasi intrinsik yang tinggi cenderung untuk melaksanakan tugas dengan lebih efisien kerana sering hadir awal ke sekolah, menghadirkan diri ke mesyuarat dan program-program sekolah. Dapatan kajian ini juga selari dengan hasil kajian Akah (2010) yang menjelaskan adanya pengaruh positif antara motivasi kerja intrinsik dan motivasi kerja ekstrinsik terhadap keefisienan kerja guru. Selain itu, Kajian Tiwari (2020) juga menjelaskan terdapat pengaruh yang kuat motivasi intrinsik dengan keefisienan kerja guru dan sebarang perubahan dalam kedua-dua motivasi ini akan menyebabkan perubahan terhadap keefisienan kerja guru.

Kajian Mruma (2013) juga mendukung dapatan kajian ini dengan menjelaskan adanya pengaruh antara motivasi kerja intrinsik dengan keefisienan kerja guru. Guru yang memiliki tahap motivasi intrinsik yang tinggi cenderung untuk lebih bertanggungjawab dalam melaksanakan tugas mereka. Namun begitu, hasil dapatan Mruma (2013) menunjukkan tidak ada hubungan yang signifikan antara motivasi ekstrinsik dengan keefisienan kerja guru. Berbeza dengan kajian Tiwari (2020), menjelaskan motivasi ekstrinsik mempunyai hubungan yang besar dengan keefisienan kerja guru seperti dapatan $\mathrm{Hu}$, Hsu, Lee, dan Chu (2007) yang melaporkan motivasi guru mempunyai pengaruh terhadap keefisienan kerja guru dan motivasi kerja guru ini boleh ditingkatkan dengan pemberian pelbagai insentif yang merupakan pendorong kepada lahirnya motivasi ekstrinsik.

\section{Kesimpulan}

Tuntasnya, kajian ini menunjukkan adanya pengaruh antara motivasi kerja intrinsik dan motivasi kerja ekstrinsik dengan keefisienan kerja guru sekolah menengah di negeri Sabah. Oleh itu, kajian-kajian berkaitan dengan variabel-variabel ini perlulah diperbanyakkan dan diperbaharui dari semasa ke semasa seiringan dengan perkembangan sistem pendidikan negara kerana motivasi kerja guru sama ada motivasi kerja intrinsik atau motivasi kerja ekstrinsik merupakan aspek yang amat mempengaruhi profesion guru dalam pelbagai termasuklah keefisienan kerja guru. Penambahbaikan dan pemantapan tahap motivasi dan keefisienan kerja guru seterusnya akan memacu kecemerlangan sistem pendidikan di negara kita. 


\section{Rujukan}

Aacha M. (2010). Motivation and the performance of primary school teachers in Uganda: a case of Kimaanya-Kyabakuza division, Masaka District. Master of Arts in Social sector Planning and Management of Makerere University, Uganda

Ada, M. J. \& Ada, J. A. (2013). Global Advanced Research. Journal of Management and Business Studies, 2(9), 439-453.

Akah, N. W. (2010) Employee motivation and performance in Ultimate Companion Limited, DoualaCameroon, Master Degree Dissertation.

Azizi Yahaya, Kim, T. S., \& Sharifudin. (2010). Stress Kerja di Kalangan Guru Aliran Teknik di Sekolah Menengah Teknik di Negeri Johor, Melaka dan Negeri Sembilan. Universiti Teknologi Malaysia.

Azllinda Binti Jaini. (2013). A Study on The Factor that Influence Employees Job Satisfaction at Scope International (M) Sdn. Bhd. Universiti Teknologi Malaysia, Shah Alam.

Bartlett, J. E., Kotrlik, J. W., \& Higgins, C. C. (2001). Organizational Research: Determining Appropriate Sample Size in Survey Research. Informational Technology, Learning, and Performance Journal, 19(1), 43-50.

Campbell, J. P. (2014). Leadership, The Old, The New, and The Timeless: A Commentary. Rumsey, M. G. Oxford Handbooks. 1-22.

Connelly, L. M. (2008). Pilot studies. Medsurg Nursing, 17(6), 411-412.

Creswell, J. W. (2008). Educational Research: Qualitative, Quantitative, and Mixed Methods Approaches (2nd ed.). Thousand Oaks: Sage Publication.

Fatmasari. (2014). Pengaruh Motivasi Kerja dan Kemampuan Mengajar Guru Terhadap Prestasi Belajar Siswa Pada Gugus Ii Sekolah Dasar Kecamatan Kebayakan Kabupaten Aceh Tengah. Jurnal Ilmiah Didaktika, 15(2), 427-441.

Fox, S., Spector, P., E., \& Miles, D. (2001). Counterproductive Work Behavior (CWB) In Response to Job Stressors and Organizational Justice: Some Mediator and Moderator Tests for Autonomy and Emotions. Journal of Vocational Behavior, 59(3), 291-309.

Habib Mat Som \& Syed Kamaruzaman Syed Ali. (2011). Komitmen Guru dalam Pelaksanaan Kurikulum dan Inovasi Berkesan. Masalah Pendidikan, 34, 99-119.

Hair, J. F., Black, W. C., Babin, B. J., \& Anderson, R. E. (2010). Multivariate Data Analysis ( $7^{\text {th }}$ ed.). New Jersey: Prentice Hall.

Herzberg, F. M. (1996). "Work and the Nature of Man". Clevelang, Ohio; World Publishers

Hong, O., C. \& Aziah Ismail. (2015). Sokongan Pihak Pengurusan Sekolah Terhadap Tekanan Kerja Guru Di Sekolah Kebangsaan Dan Sekolah Jenis Kebangsaan Cina. Jurnal Kepimpinan Pendidikan, 2(2), 42-57.

Hu, H. H., Hsu, C. T., Lee, W. R., \& Chu, C. M. 2007. A Policy-Capturing Approach to Comparing the Reward Allocation Decisions of Taiwanese and U.S. Managers. Social Behavior, 35(9), 12351250.

Kamaruzaman Kamaruddin. (2007). Tekanan Kerja di Kalangan Guru Sekolah Menengah. Jurnal Kemanusiaan, 10, 105-118.

Kelvin, L. (2016). Role of Motivation in Teacher's Job Performance In Public And Private Secondary Schools In Tabora Municipality. Dissertation master: university of Tanzania.

Krejcie, Robert V. \& Morgan Daryle W. (1970). Determining Sample Sizes for Research Activities. Educational and Psychological Measurement, 607-610.

Marican, S. (2009). Penyelidikan Sains Sosial-Pendekatan Pragmatik. Negeri Sembilan: Edusystem Sdn. Bhd.

Mruma, J.M (2013). Effect Of Motivation Factors On Teachers' Performance In Tanzanian Education Institution; A Case Of Public Secondary Schools In Nyamagana District, Mwanza. Dissertasi Master. Universiti Tanzania.

Norashid Bin Othman \& Hamzah Bin Md.Omar. (2014). Beban Tugas Dan Motivasi Pengajaran Guru Di Sekolah Menengah Daerah Ranau. Jurnal Pemikir Pendidikan, 5, 35-57.

Nurul Jalilah Binti Abdul Rahman. (2013). Pengaruh Gaya Kepimpinan Pengetua Terhadap Tahap Motivasi Kerja Guru Sekolah Menengah di Zon Bandar Segamat. Fakulti Pendidikan Universiti Teknologi Malaysia. 
Ololube, N. P. (2005). Benchmarking the Motivational Competencies of Academically Qualified Teachers and Professionally Qualified Teachers in Nigerian Secondary Schools. The African Symposium, 4(3), 17-37.

Onjoro, V., Arogo, R. B. \& Embeywa, R. E. (2015). Leadership Motivation and Mentoring Can Improve Efficiency of a Classroom Teacher and Workers in Institution. Journal of Education and Practice, 6(15), 1-15.

Penney, L. M. \& Spector, P. E. (2005). Job Stress, Incivility, and Counterproductive Work Behavior (CWB): The Moderating Role of Negative Affectivity. Journal of Organizational Behavior, 26, 777-796.

Raja Maria Diana Bt Raja Ali. (2011). Faktor-Faktor yang Mendorong Tekanan Kerja (Stres) di Kalangan Guru-Guru Sekolah Menengah di Daerah Pasir Puteh. Fakulti Pendidikan Dan Bahasa. Kelantan. Open University Malaysia.

Salanova, A., \& Kirmanen, S. 2010. Employee Satisfaction and Work Motivation Research in Prisma Mikkeli. Mikkeli University of Applied Sciences.

Sipon, S. (2007). Keberkesanan Kaunseling Kelompok Pemusatan Insan, Rasional Emotif Tingkah Laku dan Psikologi Kognitif Ad-Din Ke Atas Tahap Tekanan, Kepuasan Kerja, Strategi Berdaya Tindak dan Sokongan Sosial Guru. Universiti Kebangsaan Malaysia.

Subasi, G. (2009). I Want to Become an English Teacher in Turkey Because...International Journal of Arts and Sciences, 3(5), 137-175.

Syed Ismail bin Syed Mustapa \& Ahmad Subki bin Miskon. (2010). Buku Guru dan Cabaran Semasa. Puchong, Selangor: Multimedia Sdn. Bhd.

Syed Kamaruzaman Syed Ali, Mohd Faithal Haji Hassan, Habib Mat Som. (2017). Tekanan dan Kepuasan Kerja dalam Kalangan Guru Pendidikan Jasmani. Journal of Global Business and Social Entrepreneurship (Gbse), 1(1), 122-135.

Tajulashikin Jumahat, Fazura Mohd Noor, \& Mohd Burhan Ibrahim. (2013). Faktor-Faktor Penentu Stres Dalam Kalangan Guru: Sekolah Rendah Mubaligh Di Kuala Lumpur. Juku: Jurnal Kurikulum \& Pengajaran Asia Pacific, 1(2), 1-11.

Tiwari, P. (2020). Effect of Extrinsic And Intrinsic Motivation On Teachers Job Performance. International Journal of Current Research, 12(2), 10329-10332.

Turan, H. (2015). Taylor's "Scientific Management Principles": Contemporary Issues in Personnel Selection Period. Journal of Economics, Business and Management, 3(11), 1102-1105.

Ubom, I. U. \& Joshua, M. T. (2004). Needs Satisfaction Variables as Predictors of Job Satisfaction of Employees: Implication for Guidance and Counselling. Educational Research Journal, 4(3).

Zainab Aman \& Khairunnisa Abd Shukor. 2015. Faktor-Faktor yang mempengaruhi Prestasi Kerja dalam Kalangan Staf Sokongan Kolej Universiti Islam Antarabangsa Selangor. Proceeding of the 2nd International Conference on Management and Muamalah 2015 (2ndicomm). 16th - 17th November 2015. 